respect for my native tongue and take great pains to use it properly."

\section{Scientific Writings as Literature}

WE should, in fact, be inclined to lay the greater stress on Huxley's native taste and effort and on the favourable circumstances of his writings, and less on the detailed features which Mr. Aldous Huxley discovers-the balance of phrases, the cæsura ending, the Biblical allusions, and so forth. These are by the way. The main thing was having clear ideas and trying always to say them in the fewest and most appropriate words. The true man of science has in this respect an initial advantage over other writers, because he starts with a definite statement about something observed which he wishes to convey to his readers in the most direct and effective way. German writers do not conform to the rule owing to the complication of their tongue; but recently some professors of English in an American university compiled an anthology of extracts from the writings of men of science as a textbook for students in English. Plenty of names will occur to one at once of scientific writers who might be named in the same class as Huxley, though none perhaps so racy and pointed. His own contemporary Tyndall was one of the best. It should also be remembered that these men were living and writing at a time when a great new idea was in the air and inspiring both those who promoted it and those who were on the defensive to special mental gymnastics. No one can read Huxley without enjoying the bracing atmosphere of controversy in which he worked. He was always stript and putting the last ounce into his fencing. For this both he and we have largely to thank the doctrine of evolution. We are not so controversial at the present day, or at any rate our controversies have not the same all-pervading and stimulating effect.

\section{Manson Medal for Tropical Medical Research}

THE Manson medal for tropical medical research, given triennially by the Royal Society of Tropical Medicine and Hygiene, has this year been awarded to Dr. Theobald Smith. In association with Kilborne in 1893, Theobald Smith showed that red-water fever in cattle is transmitted by ticks, and at the same time demonstrated the passage of infection through the ova of one generation of ticks to the next. This discovery proved that a protozoal parasite of mammals could be disseminated by the bite of a blood-sucking arthropod. Probably because Theobald Smith was dealing with a cattle rather than a human disease, this great event in the history of medicine received scant recognition, though it preceded the better-known work of Bruce on the transmission of sleeping sickness and that of Ross on malaria. Indeed, Theobald Smith was the first to transfer the insect transmission theory of protozoal disease from the realms of hypothesis to those of established fact. In 1904, Theobald Smith reported anaphylactic symptoms in dogs and rabbits, and, in a letter to Ehrlich, wrote the original description of the classical anaphylactic shock in guinea-pigs often known as the Theobald Smith phenomenon. In 1907 he proved that it was possible to immunise guinea-pigs actively by the injections of a balanced mixture of diphtheria toxin and antitoxin, and two years later suggested further investigations of the method with the view of its ultimate application to human beings, thus anticipating Von Behring and Park's work by several years. The previous recipients of the Manson medal have been Sir David Bruce (1933), Senator Ettore Machiafava (1926), and Sir Ronald Ross (1929).

\section{Gravitation and Electrodynamics}

Is the last of his Rhodes lectures delivered at Oxford a year ago, Prof. A. Einstein pointed out that a defect in the original form of the general theory of relativity was that the electromagnetic field was not expressed by means of the metric of the space-time continuum as was gravitation. By introducing a modified form of the Riemann geometry admitting of distant paral. lelism, Prof. Einstein obtained field equations which he hoped would remedy this defect. From his Rouse Ball lecture at Cambridge on May 5, it appears that this method of approach has been unsuccessful. Prof. Einstein has reverted to a mathematical technique introduced by Kaluza, and has succeeded in defining a vector with four or five components in space of one less dimension. Introducing parallel displacement, a five-component vector is projected repeatedly on to a four-dimensional plane, giving rise to a curve, the properties of which provide the relationship required. In this way the extra term required to account for the phenomena of electrodynamics is obtained. The method resembles that used in building up the general theory of relativity.

\section{Twenty-one Years of Radio Communication}

WE congratulate the Wireless World on the completion of its twenty-first birthday, which is commemorated in the issue of April 27. For its first two years, the journal was known as the Marconigraph, but as the number of amateur enthusiasts was rapidly increasing, it changed its title to the more comprehensive one of the Wireless World. So far back as 1914, we find from its pages that the late Mr. Campbell Swinton practically predicted the ultimate possibilities of wireless and indicated that at no distant future we would have broadcasting. The War gave a great impetus to the development of radio. After the War, the Wireless World took a leading part in the movement for granting amateur licenses and in encouraging the 'Dutch concerts' and the transmissions from Writtle-the forerunners of wireless telephony and broadcasting. It organised communication tests between amateurs in Great Britain and America with the object of finding out whether it would be possible to bridge the Atlantic on short waves. The success of these tests led to intensive research and the discovery that these waves were ideal for distant communication. It also played a foremost part in connexion with Empire broadcasting, and helped to overcome the bitter opposition to the scheme which lasted for several years. The progress made by radio communication during the last twentyone years is marvellous. There seems no reason to doubt that equally rapid progress will be made for

$$
\text { No. 3263, VoL. 129] }
$$


many years to come. Methods of communication which twenty-one years ago stretched our imagination to the utmost are now commonplace practice. We congratulate Mr. H. S. Pocock, the editor, on the excellent work he has done.

\section{University of the Witwatersrand Library}

LAST Christmas Eve, a fire took place in the main block of the University of the Witwatersrand. As a result, very considerable damage was done: the main Library was completely destroyed, as were also the priceless Gubbins collection and the Law Library, which are, naturally, irreplaceable. Through the co-operation of the British Association and of other bodies, many replacements of lost and damaged books have been made, but in order to broaden the basis of the appeal, a meeting was held on May 9, in the council room of the Royal Empire Society, presided over by the Earl of Athlone, himself an honorary graduate of the University, the degree of LL.D. having being conferred upon him when he was the Governor-General of the Union of South Africa, during the visit of the British Association to Johannesburg in 1929. In the course of his introductory remarks, Lord Athlone traced the development of university education in South Africa, and pointed out that the University of the Witwatersrand only received its charter of incorporation ten years ago. In 1925, H.R.H. the Prince of Wales formally opened the new buildings, which occupy a magnificent site on the outskirts of the city. General Smuts was the first honorary graduate. The progress made has been remarkable, and there are now about two thousand students taking the regular courses. It was therefore a tragedy that the 'soul' of the University had been destroyed through the fire.

As a result of the meeting, which was addressed by Dr. W. Cullen, Mr. J. G. Gubbins, Prof. A. P. Newton, Sir Frank Heath, and others, a strong and representative committee, upon which Lord Athlone consented to serve, was formed to co-ordinate British efforts for restoring the library of the University. The loss includes the collection of manuscripts, books, and prints presented by Mr. Gubbins, the Hoernlé anthropological collection, in addition to all scientific journals and the departmental libraries of classics, English, Afrikaans, German, French, history, mathematics, geography, economics, and education. If the appeal for funds is successful, it is proposed to build a fireproof library, as a separate building, at an estimated cost of $£ 60,000$, a large part of which will probably be raised from people who live, or have lived, in South Africa. The chief task of the appeal committee will be, therefore, to procure books and other works to restock the library. It is, of course, impossible to replace the original documents destroyed by the fire, but it is hoped that other collections of a like kind will be fortheoming as the needs of the new library become known and the opportunity which it affords of representing every phase of South African life and culture is realised. Gifts of sets of journals and works of reference will also be gratefully accepted. All communications relating to such gifts should be sent to Dr. W. Cullen, 4 Broad Street Place, London, E.C.2.

\section{Plastic Deformation of Metals}

Dr. F. KrrBer, director of the Kaiser WilhelmInstitut für Eisenforschung, Düsseldorf, delivered the twenty-second annual May lecture of the Institute of Metals in London on May 11, on "The Plastic Deformation of Metals". Basing his remarks on the results of a series of investigations conducted at Düsseldorf during recent years, Dr. Körber dealt with the stress relationships and also with the course of the flow of the material during the most important of the mechanical shaping processes. Discussions were entered into on the conditions requisite for the commencement of plastic flow and also on the possibility of drawing conclusions from the resulting flow phenomena as to the distribution of stress in the material at the inception of deformation. The disturbances in the material in consequence of the more marked deformations in drawing, extrusion, and rolling were traced by a suitable method of investigation. The results were compared with the deformation structures obtained by X-ray methods. The knowledge of the deformation processes so obtained enabled conclusions to be drawn as to the energy or power used in the shaping operations. An exact analysis of the course of deformation in the transition zone led to estimates of the internal losses during the alterations in form. Quantitative treatment of the stress relationships which occurred in the zone of deformation is possible in so far as the pressure created at the surface of contact between the tool and the material is known by actual measurements. From the results of determinations along the roll-gap of the pressure between the rolls and the stock being rolled, a complete quantitative presentation of the distribution of stress in the transition zone between the rolls has been formulated.

\section{Electrification of Ulster}

Is the Asea Journal for February an account is given of the electricity distribution scheme in Northerm Ireland. The Irish Free State has built a large water power station on the River Shannon, on the west coast. In Northern Ireland (Ulster), there is also a considerable amount of water power available in the River Bann, which drains a large area round Lough Neagh. A scheme was recently under consideration to build a water power station on this river, but as the question is intimately connected with a land drainage scheme to be carried out by the Government, this scheme has been temporarily suspended. A steam power station has been built in Larne, on the east coast, not far from Belfast. From this station, a 33-kilovolt main transmission line has been taken over the country, through the towns of Ballyclare and Ballymena, with the view of future connexion with the River Bann. The steam power station at Larne has two turbo sets, each of 1750-kilowatt output, and a space has been reserved for one of double the size. In this way the load will be built up gradually, so that when the water power station with its comparatively high initial cost is completed, it will be possible to load it profitably from the start. The electric power will be mainly used by the linen industry, which has long flourished in Ireland. There are also paper mills and cement works in the 